\title{
Correction to: Preparing for the Next Cyber Revolution
}

\section{Correction to: \\ J. N. Pelton, Preparing for the Next Cyber Revolution, https://doi.org/10.1007/978-3-030-02137-5}

This book was inadvertently published without updating the corrections to the chapters noted below.

In Chapter 1, page 12, the text in the section "A Quick Tour Guide of the Cyber Revolution" has been replaced.

In Chapter 1, page 8, the sentence starting with "Ray Kurzweil won .... in 2015" has been corrected to read as "Greg Wyler won the Arthur C. Clarke Innovators award in 2015."

In Chapter 4, page 67, the quote at the commencement of the chapter has been corrected to read as: "A city is defined by its sense of community." Paul and Percival Goodman

The updated online versions of these chapters can be found at https://doi.org/10.1007/978-3-030-02137-5_1

https://doi.org/10.1007/978-3-030-02137-5_4

https://doi.org/10.1007/978-3-030-02137-5 